\title{
A fisionomia jurídica de São Paulo
}

Cândido Motta Filho

(Catedrático de Direito Constitucional)

A história jurídica da cidade de São Paulo pode ser apreciada nos três planos de sua história geral, isto é, na Colônia, na Monarquia e na República. Ressente-se essa história, por certo, das mesmas influências que despertaram a civilização brasileira - isto ẻ, a influência decorrente de uma civilização transplantada com a descoberta e, por isso mesmo, o período colonial é aquêle que oferece margem ao drama da transplantação de uma cultura para uma terra inculta. Daí por diante, o direito aparece como um instrumento de comportamento social e como uma aspiração, como um ideal de cultura, variável de conteúdo, mas aspirando sempre a um aperfeiçoamento contínuo, o que leva São Paulo, impulsionado pela sua Academia de Direito, a oferecer uma ampla colaboração à cultura jurídica do país.

\section{A singularidade da civilização paulista}

Quando a vila de São Paulo de Piratininga foi fundada em 25 de janeiro de 1554, a conquista estava mal começada. Os que desembarcavam na terra nova, com a alma conformada por séculos de tradição e cultura, encontravam, com a surprêsa e o desconhecido, uma ausência de repercussão para os seus sentimentos e comportamentos habituais. Muito embora quisessem prevalecer-se da 
liberdade que a terra inculta lhes proporcionava, a verdade é que, dentro de todos êles, havia a experiência da civilização de onde provinham - com seus valores próprios, na ordem religiosa, na ordem política, na ordem moral e na ordem jurídica.

Por isso mesmo ficam dramàticamente entre dois antagonismos - entre aquilo que foram e aquilo que deveriam ser por imposição do novo meio. Este, poderosamente envolvente, dissolve a possivel hierarquia de valores, de classe e de grupos. Eles traziam uma "visão do mundo" e consèquentemente uma compreensão das regras jurídicas fundamentais, nas relações de propriedade, nas relações de família, no reconhecimento das obrigações, o que representava o rei, o meirinho, o almotace, o chefe de família, o chefe militar ou o chefe de emprêsa. Mas, tudo isso se dilui, ao contato do novo meio. Não há realmente um Estado para que tudo isso se processe normalmente. $O$ país é uma terra para ser explorada, com a indiada indomável è com o conquistador aventureiro que conta consigo mesmo e com mais ninguém. Se é costume dizer-se que a história do direito do Brasil é anterior a 1500, isto não quer diżer, entretanto, que êsse direito é apenas uma continuidade exata do direito português. Este foi a raiz histórica, o ponto de partida sociológico, principalmente porque a conquista pròpriamente nada encontrou como valor institucional. $\mathrm{E}$ o pouco que encontrou não podia compreendê-lo e aceitá-lo. Assim, êsse direito português não se torna, desde logo, um instrumento de pacificação e disciplina social. Na experiência colonial, no Maranhão, encontra-se ainda essa dispersividade, essa incoerência, essa ausência de organização coletiva, o que faz com que "cada familia venha a ser uma república". Por isso, há trezentos anos, Simão de Vasconcelos podia escrever: - "nenhum homem nesta terra é repúblico, nem vale ou trata do bem comum, senão, cada um do bem particular". (História da Província de Santa Cruz). 
Não basta, para vencer as distâncias, a divisão do país em capitanias hereditárias, que proporcionam afinal, trágicos fracassos. A capitania de São Vicente, confiada a Martim Afonso de Sousa, conseguira preservar-se. Mas vivia, com suas cem léguas de costa, em permanente estado de guerra. O visconde Pôrto Seguro podia escrever, consequentemente, que "a longínqua colônia de São Vicente, que até tinha crescido com a paz em prosperidade, esteve, em consequência do trato dos navios franceses, em têrmos de ver cortadas as suas relações com a mãe pátria". (História Geral do Brasil vol. I).

O necessário era, portanto, criar um sentido da vida comum, que as capitanias não podiam, em si mesmo, proporcionar, senão fazendo o govêrno português doações, proporcionando vantagens e privilégios e fundando vilas e cidades, o que se realiza, em três tipos, os grandes domínios rurais as vilas e cidades, e o bandeirismo. Esses três aspectos marcam singularmente o estilo da civilização paulista.

Em São Paulo quer os domínios rurais, quer as cidades e vilas ficam por longo tempo em função do bandeirismo. $\mathrm{E}$ isso começa a acontecer com a fundação de Piratininga, que, no dizer de Simão de Vasconcelos, se torna "a porta do sertão".

A fundação de Piratininga assinalou o destino histórico dos paulistas. Como escreveu Paulo Prado - "tudo empurrava o bandeirante para o interior da terra: o rio, a lenda das minas de Potosi, o mistério cheio de promessas das matas quase impenetráveis, escondendo duas fontes de riqueza: - o índio e o ouro. Nessa função histórica e geográfica a bandeira resumiu tôdas as qualidades e defeitos da raça que e sapurara na segregação da montanha". (Paulística).

$O$ isolamento de Piratininga e a expansão para o interior - fixam um comportamento humano livre e autoritário. 0 paulista, para expandir-se e conquistar, precisava ter, sob pena de se considerar vencido pelo imperativo 
geográfico, o sentimento de liberdade e a inteligência para organizar. Se não se submete a el-Rei, se não recebe ordens de Salvador Corrêa, se luta contra os jesuítas, se prefere "antes quebrar que torcer", — assim o faz, para impor a sua marcha conquistadora.

O sistema jurídico reinol, não encontrando repercussão no país, não pode servir a essa gente que, com o seu quartel general em Piratininga, pretende colher os frutos da descoberta.

A impressão exterior dêsse paulista dos primeiros tempos é a de um homem que aderira à selvageria da terra. PastTells, na sua História da Companhia de Jesús, refere-se à queixa do governador do Rio da Prata contra a invasão dos aventureiros paulistas. "Ás primeiras tentativas de colonização organizada, diz Paulo Prado, o mameluco do planalto apareceu nas suas roças de Santo André e de Piratininga como um independente e, insubmisso às leis da metrópole e às ordens de seus representantes. "Antro de bandidos" - exclamou Ulrico Schmmidel, quando em 1553, na sua viagem de Assunção a São Vicente passou pelos casebres do primitivo aldeamento da Borda do Campo.

Esse sentimento robusto e indomável de liberdade era realmente comum, tão comum que mamelucos paulistas, conforme palavras de Anchieta em 1554, ameaçados dos rigores do Santo Ofício, respondeu com naturalidade e sem basófia: "Acabaremos com as inquisições a flechas".

A vida é assim impetuosa e turbulenta, o que se faz sentir desde logo, nas instituições locais, nessa Câmara de Piratininga que expulsa os jesuitas e desobedece às ordens da metrópole e não teme enfrentar, por volta de 1640 , as armas de Salvador Corrêa de Sá e Benevides.

O paulista era assim visto e autenticado como um ser primitivo e insubmisso - "gente desalmada y alevantada que no hace caso ni de las leys del Rey ni de Dios, ni tienem que veer ni cem justicias mayores deste estado" no dizer de um jesuita, em 1629. 
O esfôrço do govêrno português é para criar o espirito comunidade, o espírito urbano, porque só pela cidade é que seria possível a civilização. Mas, tôdas as vilas, formadas por ordens superiores, ressentem-se do antificialismo da imposição.

Piratininga, apesar de ficar muitas vêzes quase deserta, (Alcântara Machado - Vida e morte do bandeirante) tem vitalidade própria. Colocada entre a serra do Mar e c sertão é obrigada a manter-se por iniciativa própria.

Estudando o ante-urbanismo colonial, Oliveira Viana é obrigado a reconhecer a situação excepcional de Piratininga. "Não deixaria de ser paradoxal a formação em pleno século de uma cidade naqueles desertões do planalto paulista - e numa época em que a lavra extensiva da terra era o único meio de vida possível".

E referindo-se ainda à incapacidade democrática, em nossas cidades e vilas, escreve: "É impossível negar os fatos. Na vila de Piratininga é certo que encontramos nos quadros dos vereadores e juízes e nos altos cargos da governança - gente do povo-massa. Frequentemente, o povo-massa, a plebe citadina, aparece com os seus procuradores, reclamando, protestando, ameaçando, reivindicando direitos ou pedindo providências de interêsse local". E acrescenta: " $E$ indiscutível o fato. $O$ que é indiscutivel, porém, é a interpretação dada a êste fato, interpretação que não corresponde à sua verdadeira significação. 0 caso de Piratininga é uma exceção". (Instituições políticas brasileiras).

A vila era, realmente, "a porta do sertão", o ponto de apôio para a investida sertaneja, a organização para a liberdade na emprêsa.

O bandeirismo é que dá então o estilo da civilização paulista.' Piratininga está por todos os motivos incorporada à missão das bandeiras. E esta era, como muito bem observa Cassiano Ricardo, um "Estado em marcha" (Marcha para oeste). Aliás, Alcântara Machado explicou mui- 
to bem essa imperiosa correlação entre liberdade e organização, independentes: "Que poderìa 'valer sòzinho o indivíduo, num ambiente em que a fôrça desabusada constituía a lei suprema? Organização defensivo, o agrupamento parental exige um chefe que o conduza à feição romana: "militarmente" (Vida e morte do Bandeirante).

Cada familia era realmente uma república, mas elas se organizam e se tornam subordinadas ao espírito comum das bandeiras. Observa, a êsse propósito, Cassiano RucarDo: - "O conceito concreto e tangivel do Estado nasce, primeiro, da necessidade da defesa contra os perigos que assaltam a bandeira. Depois, ela mesmo, é um estado larvar e vivo, com um govêrno forte - um executivo que tudo dispõe e tudo ordena; enfim, uma autoridade que exerce funções policiais e judiciárias e em tôrno da qual se reunem, dentro da mais viva solidariedade, e hieràrquicamente dispostos, os elementos componentes do agrupamento". E, em seguida, assinala: "Praticam-se atos juridicos em pleno sertão para o bem e justiça dos capitães". Realmente, há um sistema de regras, mantendo a ordem e assegurando os direitos dos componentes da bandeira. O cabo de tropa, escreve Gentil de Assis Moura -- levava um regimento para a expedição e tinha, além da administração da bandeira, atribuições judiciais, distribuía datas de mineração, decidia sôbre partilha dos indios e mais descobertas e mais apreensões que faziam. Procedia arrecadação e inventário dos bens deixados pelos bandeirantes mortos no sertão e julgava os casos outros, podendo cominar pena de morte. Para o desempenho dos trabalhos forenses levava o escrivão e demais oficiais de justiça. (As bandeiras paulistas). "Na meia luz da mansa madrugada social, acentua Cassiano Ricardo, os licurgos reinóis caminhavam às tontas na tremenda incompatibilidade do artifício com a vida. 0 artifício europeu em conflito com o tumulto radioso e fecundo da vida americana. O Estado que nascia na terra entrava em choque com o Estado de fabricação peninsular 
e milenar. Êste teimava em meter o Brasil, saído da banheira, na máquina compressora das ordenações do reino". (Marcha para o oeste, $2 .^{\circ}$ vol.).

0 bandeirismo oferece, assim, pelas suas marchas pelas vilas, cidades e fazendas que semeia, a grande experiência jurídica dos paulistas. Com êle, o direito, como regra de ação social e como proteção do indivíduo, muito embora não perca os fundamentos de sua razão de ser, toma a colaboração do meio e se aproxima assim da autênticidade. Os membros da vereança, o Procurador do povo, os encarregados da justiça, nas vilas, sentem, no exemplo das bandeiras, a solução possível. Ésse é o motivo pelo qual um organizador de bandeiras podia escrever: "Os elementos que reuni nesta bandeira não são daqueles que estão inscritos nos livros de Vossa Majestade".

Não havia, "na época puramente paulista" como pensava Oliveira Viana, " tendência anti urbana", mas ao contrário. Etravés da concepção jurídica decorrente do bandeirismo, que transforma a aventura sertaneja em fôrça organizada, que se realiza a primeira tentativa de harmonia entre a vila e o sertão, entre a civilização e a natureza.

Quem toma conhecimento da maneira pela qual as autoridades judiciais da Colônia resolvem os "casos jurídicos" que surgem em São Paulo, verifica que, muito embora haja um acentuado desvio da maneira portuguêsa pela imposição dos costumes locais, permanece, entretanto, o ideal jurídico da civilização transplantada, o mesmo ideal do justo, o mesmo sentimento da lei.

A obra jurídica portuguêsa aparece sobrecarregada de compromissos para com o passado. Ainda livre dos ataques revolucionários, ela se harmoniza perfeitamente com a realidade existente.

A monarquia absoluta não conhecia limitação legal à sua ação governativa. Conhecia algumas leis chamadas "fundamentais", espécie de acôrdo entre o rei e o povo, tradicional- 
mente reconhecido e que, impostas ao soberano, só em Côrtes podiam ser alteradas, em Côrtes. (Cabral Moncada, Estudo de História do Direito, $20^{\circ}$ vol.).

Havia uma correspondência entre o poder e o povo e, com isso, o reconhecimento das relações jurídicas, quer no campo do direito público, quer no campo do direito privado. Por isso, embora prevalecesse, na órbita legislativa, a vontade do príncipe, no judicial, a confusão e a incerteza de atribuições, havia uma aceitação de tudo isso, como resultado natural de um estado de cultura.

Na Colônia, porém, não se podia verificar a existência de uma ordem política, a presença de um Estado. O que se verificava, no palco da conquista, era a de leis sem costumes, de regras sem direito, de instituições sem povo. Lembra OLIveira Lima, como se acentuava no país a venalidade dos magistrados, o império do faccionismo nos julgagados, acumulado ainda mais pelo arbítrio dos capitães generais, que podiam revogar, à vontade, sentenças legitimamente proferidas. Contra os juizes venais havia o recurso para os juízes e tribunais superiores. Mas tôda a maquinária judiciária, com seus ouvidores, corregedores, com as Relações e o Desembargo do Paço, funciona mal. E nota Oliveira Lima que à confiança respondia à confiança nas relações de indivíduos para individuos, não de indivíduos para a autoridade. (D. João VI).

Este funcionamento arbitrário e venal faz surgir um funcionamento marginal, imposto pelo direito vivo e pela necessidade de garantias que a conquista da terra e do ouro impunha (Revista do Arquivo Municipal de São Paulo, N. ${ }^{\circ}$ XCVII).

Nota-se que o aspecto feroz bravio e indomável do I, II e III séculos se transforma e se define na procura de uma ordem. Mas êsse período inicial foi de fecundação. "O cabo de tropa paulista do século II e III, - escreve Orveira Viana, - foi, sem dúvida, o personagem mais poderoso e fecundo na criação do nosso direito público: - - 
primeiro - porque era uma causa de conflitos constantes com os castelhanos, incorporando o nosso domínio, com o recuo do meridiano, vastas extensões de terras que não nos pertenciam; segundo - porque era um agente frequente de conflitos e perturbações de ordem pública, pelos seus golpes de fôrça, como "potentados em arcos"; terceiro, porque representava um centro de autoridade social, com que a Metrópole sempre contou para dirigir e realizar o govêrno das vilas e povoações dos "borders" da região sertaneja, na qualidade de capitão-mór regente". (Instituições políticas, $10^{\circ}$ 'vol.).

O sentimento de um direito nosso sai do bandeirismo quando êsse desperta, pelo aumento da exploração reinal, a consciência de exploração indevida do esfôrço alheio. E depois se amplia e envolve o país, porque o bandeirismo, com suas características paulistas, torna-se um movimento nacional decisivo para a forma de uma consciência comum. Estudando o processo criminal, nos tempos coloniais, João Mendes mostra que, no país não havia só o que explorar e também o que conservar; assim, a carta régia de 20 de janeiro de 1745 afirmava ao Corregedor de crime na Côrte que "o legislador é mais empenhado na conservação dos vassalos do que nos castigos de justiça, e não quer que os ministros procurem achar nas leis maior rigor do que elas impõem". (Processso Criminal Brasileiro).

Por muito tempo se aquieta o espírito paulista. A riqueza que êle descobrira fôra desterrada sem nenhum proveito para êle. A vida se processa na acomodação possível das leis da metrópole ao meio compassivo. 0 bandeirante transformara-se em colono e povoador e depois se conformara com a perda das minas. Mas nessa aparente submissão, que se assemelha, segundo Paulo Prado, a uma decadência, o direito, como necessidade social, vai procurando o seu caminho, nas próprias negativas que sofre, nas violências que procuram desmoralizá-lo. A tirania dos capitães generais, a ganância do fisco, a carestia de gêneros e 
principalmente de sal, a ameaça de miséria, prepara o clima para a independência. Já em 1775 o governador Martins Soares escrevia ao vice-rei e se referia "aos paulistas com ânimo abatido, e desconfiados, muitos fugidos pelos matos, e todos padecendo extorções e violências". E quando José Bonifácio inicia a sua genial empreitada política, a terra paulista era um cenário propício.

\section{O amanhecer de uma consciência jurídica.}

No período colonial que oferece aparentemente um cenário de subordinação, o que há, realmente, é insubordinação. $O$ colono trouxera consigo um espirito de inconformado e foi com êsse espírito que a Colônia começou a ter vida própria. Muito embora criados, como dizia o procurador do Maranhão, Guedes Aranha, em 1654, "com o leite da Igreja e da fé cristã, os habitantes do país formavam um novo estilo de vida". Certos de que não havia organização, nem cultura sedimentada, êsses habitantes se voltavam para a Côrte. Mandar o filho para Coimbra era o ideal do senhor de engenho. Mas, essa estada em Coimbra ou em Montpellier serve para aprimorar o espírito de rebeldia.

Em Coimbra acentua no brasileiro suas características de estrangeiro e é por isso, consequentemente, olhado com desconfiança. Antônio Carlos Ribeiro de Andrade, nascido em Santos, em 17-9-73, participa da revolução pernambucana, e tinha por alcunha "Mirabeau brasileiro".

E José Bonifácio, também nascido em Santos, tem o destino histórico de planejar e realizar a independência do país.

A sua preocupação inicial no país livre é o de vê-lo intelectualmente livre.

Recusava Portugal até então ensino universitário ao país. Durante a ocupação holandesa, em 1654, planeja-se uma Universidade para Recife. Com a presença de D. João VI no país, abrira-se uma universidade na Bahia. Os inconfidentes já tinham sonhado uma Universidade em Vila 
Rica. Mais tarde, das instruções que os deputados paulistas deviam apresentar às Côrtes, como voto do govêrno da Província, redigidas por uma comissão justamente nomeada por José Bonifácio, aprovadas em 3 de outubro de 1821, consta a conveniência da criação de uma universidade.

A independência, por sua vez, criando uma situação insuportável para os brasileiros que pretendessem estudar em Coimbra, força, desde logo, uma solução brasileira. Sôbre essa solução é que se preocupa José Bonifácio, que de acôrdo com os informes de seu irmão Antônio Carlos, chegara a escrever "Memória e Regime das Universidades do Império".

Os cursos superiores no país só se tornam, entretanto, realidade, quando, por indicação de Fernandes Pinheiro, visconde de São Leopoldo, oferecida em agôsto de 1823, a Comissão de Instrução Pública, recomenda a criação de dois cursos superiores, um em Olinda e outro em São Paulo. Não houve, a princípio, acôrdo sôbre a sede dêsses cursos.

José da Silva Lisboa, que foi o Visconde de Caírú, entendia que o privilégio da sede deveria caber à Bahia. São Paulo não servia, para êle, porque "a pronúncia incorreta e o dialeto desagradável dos paulistas havia de influir para que a mocidade adquirisse o mesmo defeito".

Não influiu, entretanto, a reserva do iminente homem público. São Paulo era cidade que se abrira para o sertão, que somara ao seu particularismo admiráveis condições históricas. tendo sido, por esfôrço de um de seus maiores filhos, o berço da independência.

0 projeto estabelecera que se criasse um curso juridico na cidade de São Paulo, no qual fôssem adotados provisòriamente os estatutos da Universidade de Coimbra, com as alterações que fôssem julgadas "adequadas às circunstâncias e às luzes do século".

Muito embora fôsse dissolvida a Constituinte do Império, em 12 de novembro de 1823 e com isso não fôsse promulgada a lei referente aos cursos, êstes foram, por ato 
legislativo, fundados em 27 de agôsto de 1827, que foi significativamente referendado pelo então ministro Visconde DE CaIRú. Em suas "Memórias" escreveu mais tarde: "Ao tempo dêste Ministério pertence o ato que reputo o mais glorioso de minha carreira política e que me penetrou do mais íntimo júbilo, que pode sentir o homem público no exercício de suas funções. Refiro-me à instalação dos dois cursos jurídicos de São Paulo e de Olinda, consagração definitiva da idéia, que eu aventurara na Assembléia Constituinte, em sessão de 14 de junho".

Inaugura-se, pois, em $10^{\circ}$ de março de 1828, o curso jurídico em São Paulo, pelo professor José Maria de Avelar Brotero.

As consequências da criação da escola de direito, na pequena cidade provinciana, foram, desde logo, sentidas. A cidade é conquistada pelo espírito acadêmico que, dai por diante, a dirige, a define, por muito tempo, porque a escola não é só um centro de preparação jurídica, mas uma escola de índole universitária, centro de convergência literária e de ambições sociais e políticas.

O ensino do direito, para alcançar o seu sentido técnico e profissional, não só requer o conhecimento de idéias gerais, de princípios filosóficos, de valores literários, como também desperta o gôsto por êsses conhecimentos. Transforma-se num elemento espontâneo de integração e interêsse coletivo. Ésse é o motivo pelo qual a Academia de Direito, antes de ter uma influência cultural, pelo trabalho de seus mestres e alunos, tem essa influência social na transfiguração da mentalidade.

No artificialismo e na deficiência das instituições importadas, num pais de cultura restrita e rudimentar, aparece uma nova mentalidade, inteiramente diversa daquela do bandeirismo, mentalidade de alcance mais amplo e de compreensão mais universal.

Em um país unitário, sob as exigências de uma independência conquistada sem guerras, São Paulo reflete como 
cidade, os múltiplos aspectos de um difícil e complicado período de organização. A cidade, como capital da província, com uma Faculdade de Direito iniciante, continua a colher as instituições do direito português àquilo que estava nas Ordenações do Reino ou que o romantismo impunha, filtrado pela jurisprudência, depois as novas tendências do século dezoito, a lei da Boa Razão ou a obra de Melo Freire. País de civilização transplantada, não podia possuir realmente um direito próprio. Punha, porém, a sua esperança, num desenvolvimento mais cabal de consciência jurídica, com a criação da escola de São Paulo.

"Cedendo provàvelmente à intuição de que nela (a cultura jurídica) reside o eixo de tôda a civilização cristã", disse Rui Barbosa, - “o regime imperial quase logo após a nossa independência consagrou ao direito duas faculdades, uma ao norte, outra ao sul, como situações polares, dominantes no nosso mundo moral. Sem desfazer, porém, na realeza de Olinda, a pérola do norte, amortecida, talvez mas não desluzida jamais de seu oriente, não se poderia sèriamente duvidar que o magistério de São Paulo exerceu sempre um grau mais alto, com influência muito mais poderosa e muito mais larga amplitude, a sua missão nacional". E acrescenta, com sua luminosa eloquência: "Bolonha, famosa outrora entre as cidades letradas, pela sua "universidade scholarium" e pelos seus "doctores legentes", se chamava por autonomásia a um tempo "a douta e a livre", associando nas suas antigas moedas e legenda solene de seus direitos - "libertas", o fôro por excelência de mestre "Bononia docet". A São Paulo, indisputàvelmente, lhe cabem os dois títulos no mesmo brasão: - "professa a liberdade e ensina a Justiça."

Muito embora não recusando o influxo coimbrão, tendo como professôres mestres preparados em Coimbra, a Faculdade de Direito de São Paulo inicia a emancipação intelectual da cultura brasileira. 
A cidade realmente se transfigura. Toma nova fisionomia, adquire novos centros de interêsse, dos seus novos problemas, amolda, por fim, uma nova mentalidade. $O$ seu primeiro diretor, tenente general dr. José Arouche Rendon, era português. Mas seus olhos estão voltados para a terra em que vive, para a cidade onde acumula seus interêsses. Publica então "Elementos de Processo Civil", procedidos de instruções municipais. E, entre os trinta e três primeiros alunos, surgem Manuel Valdetaro Dias da Mota, Azevedo Marques, Amaral Gurgel, Dias de Toledo e Pimenta Bueno, futuro ministro do Império e autorizado comentarista da Constituição de 1824.

Em meio a uma atmosfera verdadeiramente universitária, onde nasce uma romântica curiosidade intelectual, a influência do direito não se faz sentir tão sòmente na cảtedra, mas também em obras publicadas.

A necessidade de ensinar e o desejo de aprender provocam uma certa mobilização espiritual. O país, em organização, começa a ser observado, quer no seu comportamento social, quer no seu comportamento político. $O$ encontro e o desencontro de interêsses, os problemas decorrentes da antiga situação jurídica, a maneira pela qual se distribuía e se exercitava o direito de propriedade numa província que começa a sua recuperação agrícola, pelo café, através do braço escravo, os usos e costumes que se formavam imperiosamente ao lado das instituições; a crença religiosa, a concepção do casamento e da família, o desenvolvimento do patriarcalismo rural; a maneira pela qual se comportava a Justiça e os representantes dos constituídos - não só provocavam ou exigiam a presença do advogado, como também assinalavam a existência de um amplo campo de ação para aquêles que desejavam tomar posição na vida do país.

Antes, era a dependência, o país sem vida própria. Capistrano de Abreu recordava Luccock: - "tôda a população parecia de língua atada" Para Martins Júnior, de 
1808 a 1822, o direito nacional se revela pela quase exclusiva predominância dos institutos de direito publico interno e externo; medidas políticas, administrativas, financeiras e diplomáticas. " No "Correio Brasiliense", de novembro de 1810, Hipólito José da Costa criticava jocosamente a maneira servil com que se aparelhava o país, tudo de acôrdo com o Almanaque de Lisboa. Num país até sua independência, sem escolas superiores, sem tipógrafos, que só recebia livros de fora mediante prévia licença do Desembargo do Paço - a mentalidade que se forma e que aspira à liberdade, não pode contar com o material do meio em que desperta, porque êsse meio era culturalmente negativo. "Com efeito, escreve Euclides da Cunha, - legislar para o Brasil de 1823 seria tudo, menos obedecer à consulta lúcida do meio"

A cidade de São Paulo, depois de 1827, com o seu curso jurídico instalado no Largo São Francisco, abre um novo caminho, cria realmente um novo cenário. Assim, por exemplo, no Regulamento dos cursos elaborado pelo Conselheiro de Estado, Visconde de Cachoeira, já se cuidava de ensinar de conformidade com as exigências do meio. $O$ professor, diz êle, explicará “o direito público pátrio, definindo-o competentemente, e extremando-o do particular, e regulando-se pelas disposições gerais do direito público universal, fará aplicação de seus princípios ao que há de semelhante na legislação pátria, e dará a conhecer aos seus ouvintes a constituição antiga da Monarquia e a atual do Império".

Mais tarde, com a reforma de Franco de Sá (Dec. n. ${ }^{\circ}$ 9360, de 17-1-1885), instituiu-se o ensino da História do Direito Nacional.

A concepção que, mais tarde, dominou, de que o bacharelismo artificializou o país, com uma cultura exterior de importação - é absolutamente falsa. A Faculdade de Direito força, pelo ensino do direito, ao conhecimento da realidade social, porque não há direito sem essa realidade. 
Regulando a vida e os interèsses da vida, exige, por sua própria índole e vocação, o conhecimento dos dados sociais da existência. O bacharel tem uma arma para a luta e essa arma tem realmente extraordinário poder atuante, provocando, estimulando ou contendo a massa das atividades coexistenciais. A simples aplicação da lei ao fato deixa, desde logo, de ser simples, frente à complexidade dinâmica da vida em comum. O exemplo vivo dessa experiência fundamental surge nas consequências provindas das modificações legislativas, com a lei de 19 de outubro de 1828, que reorganiza os municípios no pais ou com o Código de Processo de 1832 que, com sua ampla e generosa tendência descentralizadora, oferece novas possibilidades às províncias. Como diz Oliveira Viana, "êste código, com sua democracia municipalista, obrigava, forçava, mesmo, os senhores rurais a entendimentos e combinações entre si para elegerem as autoridades locais, como os juízes-de-paz (que tinham funções policiais); os juizes municipais (que eram juízes do crime e tinham também certas funções policiais); os vereadores e os oficiais da Guarda Nacional".

Adquirindo com a lei dos municípios e principalmente o Código de Processo, possibilidade de cuidar de seus próprios interêsses, a Província adquïre novas possibilidades para desenvolver-se e, com a Província, a cidade de São Paulo.

Já não é tão só o centro universitário, a cidade dos estudantes, cenáculo boêmio das expansões acadêmicas. Há interêsses políticos de monta na cidade. Há o despertar de interêsses maiores em seu meio.

João de Melo Alves, com o pseudônimo de Hinckmar, publica, em 1882, suas impressões sôbre cinco anos de Academia. Refere-se ao pensamento filosófico, à influência do krausimo na evolução do direito, ao dualismo, ao panteirismo, ao positivismo. Para êle, Kant concebeu o "harmonismo" e Krause o "realismo".

$E$ interessante ver, principalmente, a partir de 1840 , 
um visível interêsse pela geral e pela filosofia jurídica, onde se percebe a influência de Kant e de Krause. O romantismo formula as grandes interrogações da vida. Alvares de Azevedo é estudante de direito, preocupado com os seus problemas formais e fundamentais e, ao mesmo tempo, poeta, fazendo interrogações ao destino. Enquanto que, para uns, Kant é o novo depositário da verdade, o filósofo do mundo moderno como o filósofo da liberdade; para outros e, principalmente, para alguns professôres da Faculdade, um metafísico nebuloso e incompreensivo, fruto suspeito do protestantismo luterano, que precisava ser afastado pela filosofia perene, posta dentro do espírito cristão, com ordem, pêso e medida, por Santo Tomás de Aquino.

Não havia, na cidade, já tocada de múltiplas influências, o aspecto polêmico que luminosamente surgiu em Recife, com Tobias Barreto e seus companheiros. A filosofia, ligada às concepções políticas e jurídicas, ao liberalismo fundamental que eclodira na província, com o movimento revolucionário de 1842, aparece nas obras jurídicas, mais como ponto de apôio para conclusões práticas, para soluções necessárias, do que, pròpriamente, como problema. O Conselheiro José Maria de Avelar Brotero, que nascera em Lisboa, em 1798 e que fôra professor durante quarenta-e-quatro anos, se abalançara a escrever sôbre os princípios de direito natural e depois sôbre os princípios de direito universal. Os seus trabalhos, que não denotam qualquer espécie de inquietação filosófica, restringem-se a um simples caráter esclarecedor e informativo, muito embora não revelem a necessária ordem e clareza.

Mais acentuada e muito mais marcada é a obra do Conselheiro da Veiga Xavier.

E fruto, porém, de um espírito muito mais curioso do que polêmico. A sua influência, muito embora repetidas vêzes notada, não tem o encanto das revelações e das novidades. 
Mais tarde, depois de um período de desinteressante mediocridade, onde o ensino das idéias gerais assume um aspecto enfadonho dos assuntos desinteressantes com. a reação ao romantismo, ao subjetivismo, surge o naturalismo, o cientismo, o experimentalismo, o evolucionismo, que se situam na geração revolucionária e republicana e que vai produzir, na Faculdade de Direito, mestres, como Pedro Lessa, Cândido Mota e João Arruda. Pedro Lessa publica, em 1905, um trabalho sôbre "O determinismo psiquico e a imputabilidade e responsabilidade criminais" e, em 1912, seus estudos sốbre "Estudos de Filosofia do Direito". Cândido Mota transporta para suas aulas, a sua adesão à "escola positiva" italiana com suas obras sôbre a "Classificação dos delinquentes", seus estudos sôbre a delinquência infantil e sôbre a nova política penitenciária. João Arruda com suas lições de Filosofia do Direito e seus notáveis estudos sôbre a ciência jurídica e a filosofia política.

Mas, o direito, como a ciência da harmonia social, fascina os espíritos estudiosos que vêem a sua existência ou a encarnação na atividade processual. Se um Veiga Cabral publica, em 1859, o seu "Direito Administrativo", o Conselheiro Tomás José Pinto Cerqueira publica o seu "Código de Processo Criminal" e o seu "Tratado Regular Prático dos Testamentos", o Conselheiro Manuel Dias de Toledo suas "Lições Acadêmicas" e "Anotações aos elementos do Processo Civil", o Conselheiro Francisco Furtado, os seus "Tratado de Testamento", "Código de Processo Criminal". O Conselheiro Inácio Ramalho - os "Elementos de processo criminal", "Pratica civil e comercial", "Praxe brasileira", "Apostilas de Prática", o Conselheiro Antônio Ribas, sua ampla obra jurídica: "Curso de Direito Civil brasileiro", "Direito Administrativo", "Da posse das ações possessórias, segundo o Direito Pátrio comparado com o direito romano", "Consolidação das leis do Processo Civil”, João Monterro, com sua empolgante obra, volumosa e variada, distinguindo-se nela a sua "Teoria do Processo Civil e Comercial"; 
o Conselheiro Manuel Duarte de Azevedo, com o seu "Projeto de Código de Processo Criminal do Estado de São. Paulo", com o seu "Projeto de Código Civil e Comercial"; Dino Bueno, no estudo que fêz como relator da Comissão Revisora do "Projeto do Código Civil; Joño Mendes dE ALMEIDA JUNIOR também com uma extensa e luminosa atividade jurídica, publicando, entre outras, a "Exposição. preliminar das bases para a reforma judiciária do Estado de São Paulo", "As formas orgânicas da Praxe Forense", "Plano de reforma judiciária", "A uniformidade, a simplicidade e a economia do nosso processo forense", " $O$ processo criminal brasileiro".

A monarquia se abastece, em São Paulo, dela retirando estadistas e juristas de nomeada como o MARQUÊS DE SÃo. VICENTE, que escreveu "Apontamentos sôbre as formalidades do Processo Civil”, "Direito Público Brasileiro e a análise da Constituição do Império", "Considerações relativas. ao beneplácito", "Reforma eleitoral". Também José BonIFácıo, o moço, professor de largos recursos, cujo perfil foi traçado, em página memorável por Rui Barbosa. Entre. suas abras, é oportuno revelar a "Memória histórica dos acontecimentos mais notáveis da Faculdade de Direito de São Paulo". A monarquia apela também para outros paulistas e ilustres, saídos da Faculdade de Direito, como o, Conselheiro Rodrigues Alves, que, depois, foi presidente da República.

Da Faculdade saem, realmente, homens da estatura de: um Rio Branco, de um Rui Barbosa, de um Afonso Pena, de um Conselheiro Saraiva, de um Joaguim Nabuco.

Quando, em 1889, se proclama a República, a cidade de: São Paulo já possuía outro aspecto. A Faculdade adquirira. extraordinário prestígio e ela, que também fornecera contingente decisivo para a vitória republicana, ia ser uma das. bases essenciais da vida jurídica no novo regime.

A cidade é a capital do Estado, a sede do govêrno. Mantém suas tradições municipais, sua Câmara Municipal 
e o seu prefeito. O Estado federal dava à antiga província as prerrogativas de Éstado membro, dotado de autonomia política com o direito de autorganização e autodireção. Já, em 1870, o Manifesto Republicano pleiteava pela dualidade de justiça. E o projeto de Constituição para São Paulo, elaborado pelos propagandistas republicanos em 1873, instituía nos artigos 28 e 26, um poder judiciário local.

Logo após à proclamação da República, começa ̀̀ cidade de São Paulo as novas vantagens da descentralização operada no país. A agricultura, apoiada por longos anos, no braço escravo, já estava recebendo as primeiras levas de imigrantes que vinhham contratados para a lavoura. 0 comércio torna-se mais intenso, os bancos e os estabelecimentos de crédito se multiplicam. Aparecem as escolas primárias, estabelecimentos de ensino secundário. Surge a Escola Politécnica e depois a Escola de Farmácia e Odontologia, a Escola Agrícola "Luiz de Queiroz".

A cidade não é mais acadếmica, mas um centro de múltiplos interêsses para o desenvolvimento da cultura jurídica. A primeira constituinte republicana revela-se como uma assembléia de verdadeiros mestres de direito público. Essa, que se reune periòdicamente, acolhe as vozes autorizadas de mestres e juristas, como Aimeida Nogueira, Herculano de Freitas, Washinton Luis, Dino Bueno, Candido Mota, Pinto Ferraz, Fontes Júnior, Rafael Sampaio, Alcântara Machado e tantos outros.

Cuida o govêrno do Estado do problema das terras públicas, da discriminação das terras devolutas. Partem da Assembléia Legislativa do Estado as primeiras leis de defesa dos trabalhadores agrícolas. Do projeto de organização judiciária de 1898 de CÂNDIDo Mota já figura no parágrafo único do artiío $\cdot 7^{\circ}$, o seguinte dispositivo: -

"O produto da multa dos jurados constituirá renda do Estado, e será destinado à indenização das testemunhas operárias que perdem um ou mais dias de serviço para 
atender aos reclamos da Justiça. Essa indenização será correspondente a dois têrços do salário perdido e devidamente comprovado a juízo do exator".

Posteriormente, foi criado o Patronato Agricola, destinado a defender o trabalhador agrícola. Surge o serviço de imigração, com a sua agência de colocação. Com o desenvolvimento industrial, amplia-se a ação do Estado e o dr. Giovanni Bonacci, já em 1919, podia aplaudir em seu livro, as garantias oferecidas ao imigrante italiano (L'Italia Vittoriosa e la sua espansione nel mundo).

Locchi e Montara recomendavam São Paulo para o trabalhador italiano, dizendo:-

"Hoje, São Paulo já possui leis sociais de primeiríssima ordem; aspirações de outros países lá já são um fato realizado: o dia de oito horas, por exemplo, era regularmente observado por todos desde 1919, antes mesmo que o Govêrno Federal tivesse tratado de estendê-lo a todo o Brasil, coisa necessária para evitar uma disparidade de tratamento".

Organiza-se a luta contra a criminalidade, em moldes inteiramente modernos, com a inauguração da Penitenciária modêlo de Carandirú e com a inauguração no bairro do Tatuapé, do Instituto Disciplinar para o tratamento de menores abandonados e difíceis.

Com a competência estadual para legislar sôbre processo, surge o modelar Código de Processo Estadual, fruto de um trabalho feito por uma Comissão composta de Alcântara Machado, Costa Manso, Dino Bueno, Estevam de Almeida, José Augusto César, Rafael Sampaio.

De conformidade com a Constituição do Estado, o Senado estadual toma uma posição singular ña defesa dos municípios. Era de sua competência privativa resolver acerca dos recursos dos atos e deliberações das municipalidades. Esses atos e deliberações poderiam ser anulados quando contrários à Constituição e às leis do Estado; quando ofendiam direitos de outros municipios. 
A cidade de São Paulo torna-se dêsse modo uma explêndida oficina de experiência juridica durante a primeira república. Não só revelou, pela Faculdade de Direito, notáveis mestres em todos os ramos da ciência jurídica, como também, na feitura de suas leis, na criação e organização de suas instituições sociais, políticas e administrativas. Seus tribunais se prestigiaram pela firmeza e critério jurídico de suas decisões e julgados e várias revistas especializadas, entre elas o "São Paulo Judiciário", a "Revista dos Tribunais", se tornaram o repositório da atividade jurídica nos seus mais variados aspectos.

Depois de 1930, apesar do crescente esfôrço pela centralização política, apesar das revoluções, dos desentendimentos, da supressão prolongada das instituições livres, a cidade continuava a sua faina construtiva, melhorando, o quanto possível, suas instituições. Ampliou-se o serviço social do Estado com o Departamento Estadual do Trabalho, com o Departamento Serviço Social do Estado, a criação da assistência técnico-legislativa, etc.

Por certo que tudo isso se vem fazendo, nas incertezas da crise nacional, por entre as contradições de governos por oposições e governos eleitos, com as consequências visíveis de vários rumos constitucionais que deram já ao Estado duas constituições.

A Faculdade de Direito, modernizada, magnificamente instalada, com perto de trê mil alunos, é hoje um dos estabelecimentos modelares da América.

Essa atividade jurídica, desenvolvida em quatrocentos anos de existência da cidade que aqui assinalamos, resumidamente, mostra que a cidade de São Paulo soube manter, no gôsto pela liberdade e pelo progresso, a sua convicção de que só pela ordem jurídica e pelo culto pelo direito é que uma coletividade sustenta a sua vida e faz de suas glórias um impulso para o futuro. 